\title{
A multiscale gaming approach to understand farmer's decision making in the boom of maize cultivation in Laos
}

\author{
Christine Ornetsmüller $^{1}$, Jean-Christophe Castella ${ }^{2,3}$ and Peter H. Verburg ${ }^{1,4}$
}

\begin{abstract}
In Southeast Asia, the rapid expansion of boom crops like hybrid maize, rubber, oil palm, or banana, has brought about daunting environmental and socioeconomic impacts such as deforestation, land degradation, and indebtedness. Why do farmers engage in and keep on pursuing this farming strategy despite the adverse effects on local landscapes and livelihoods? In the context of the northern uplands of Lao People's Democratic Republic (Lao PDR), we developed an innovative approach to understanding the decisions that lead to the emergence of the maize boom. We successively studied the adoption, expansion, intensification, diversification, and abandonment of intensive maize practices in locations in which these phases were ongoing at the time of study. To better contextualize decision making, we designed and applied local, serious games with farmers in seven different villages that were going through a maize boom. Then we designed a metagame that summarized our findings across all decision phases and local games in a generalized form. National agricultural experts validated the structure of the metagame by taking on the role of farmers and they witnessed that their cumulative decision making within the metagame lead to a maize boom too. Core findings include: (1) the maize boom and bust can be reproduced in a game environment that simulates the change of six factor combinations; and (2) Farmers in northern Laos reinvest maize profits into their long-term, socioeconomic goals. The approach presented combines micro- and macrolevel analysis of land-use change. On the one hand, it allows the exploration of the local, social-ecological contexts of land-use decisions. On the other hand, it provides a systematic procedure to scale up, generalize, and test the contextual knowledge and systemic understanding of a complex, large-scale land-use change process.
\end{abstract}

Key Words: agrarian transition; boom crop; decision making; gaming and simulation; land-use trajectory; Southeast Asia

\section{INTRODUCTION}

\section{Boom crops as drivers of the agrarian transition in Southeast Asia}

The agrarian transition in Southeast Asia is a long-term and largescale process of social-ecological transformation. It is often referred to as a shift from a subsistence-based to a market-oriented economy and society (De Koninck 2004, Messerli et al. 2015). Although this may sound like a single trajectory on the macrolevel, it is rather a cumulative effect of multiple, locally specific trajectories (Castella 2012). The variety of trajectories of land systems emerges from overlapping processes of urbanization, market integration, and commodification of labor and land, which occur in different historical and geographic contexts (Lund 2011). Land-use conversions of slow and fast nature take place; these include gradual, incremental changes that slowly advance market integration as well as abrupt, profound changes that accelerate the transition process (Müller et al. 2014).

Crop booms are abrupt land-use changes that accelerate the agrarian transition. They have appeared repeatedly in different countries of Southeast Asia and are driven by the international market demand of land-based commodities such as palm oil, rubber, banana, coffee, or hybrid maize (van den Top 1995, Fox and Castella 2013, Cramb et al. 2017). Within a decade or less, a particular crop expands rapidly and can quickly disappear again. Hall (2011) defined crop booms as fast increases in the amount of land that is devoted to the production of high value crops through monocropping. Building on this definition, the change of cropping area in a commodity boom can be linked to and conceptualized as a series of decisions by farmers to adopt, expand, intensify, diversify, and abandon a cash crop. Each decision bears consequences for the whole land use at the household, village, or regional level. Although crop booms bring economic growth on an aggregate level, they can also foster land degradation and inequality, e.g., between early adopters and others (Rigg and Vandergeest 2011, Byerlee 2014, Cramb et al. 2017).

Both large agribusinesses and smallholder farmers have engaged in crop booms (Hall 2011, Cramb et al. 2017). The surge of largescale land acquisitions for cash crop production, particularly in the last decade, has been in the spotlight of media and research communities as drivers of land-use change and the commodification of farming (Rulli et al. 2012, Heinimann and Messerli 2013, Kugelman 2013, Hirsch and Scurrah 2015). However, in many situations smallholders can also be collectively responsible for large-scale and rapid deforestation. They expand cash cropping onto land that was previously used for shifting cultivation, agro-forestry, or other types of forest cover (Vongvisouk et al. 2016). Despite the risks to their livelihoods and environment, smallholders are attracted by the lucrative opportunities of boom crops.

A recent case of a crop boom occurred in the northern uplands of Lao People's Democratic Republic (Laos). Lestrelin and Castella (2011) reported that maize production has skyrocketed from the early 2000s and stemmed mainly from the work of

\footnotetext{
${ }^{1}$ Department Environmental Geography, IVM Institute for Environmental Studies, VU University Amsterdam, The Netherlands, ${ }^{2}$ IRD, Institut de Recherche pour le Développement, Université de Montpellier, Montpellier, France, ${ }^{3}$ CIRAD, UR AIDA, Montpellier, France, ${ }^{4}$ Swiss Federal Research Institute WSL, Switzerland
} 
smallholder farmers (hereafter referred to as either farmers or smallholders). The boom was triggered by the introduction of new hybrid maize cultivars and the opening of cross-border trade in response to high market demand in the neighboring countries, Thailand, Vietnam, and China in which the maize was used as feed for the expanding livestock industry (Thanichanon 2015). Although the new cash crop created opportunities for farmers to generate higher income, it involved risks of becoming indebted to input suppliers and/or dependent on maize market fluctuations and export prices. The expansion of maize monocropping resulted in land degradation including deforestation, loss of biodiversity, nutrient depletion, soil erosion, and chemical pollution due to herbicides and fertilizers (Lestrelin 2010). On top of that, staple crop production was affected because the soil eroding from the sloping maize fields accumulated in paddy rice fields after heavy precipitation and thus clogged the irrigation channels (Castella 2012).

\section{Studying land-use decisions in crop boom trajectories at local and regional levels}

Approaches to better understand the phenomenon of crop booms need to address different spatial scales, because of the complex interplay of underlying processes, the high diversity of local trajectories, and the fast pace of change. We identified three levels to study land-use change in connection with the agrarian transition and crop booms: (1) the transformation of socialecological systems at the regional level, consisting of (2) land-use trajectories at the community level, which emerge from (3) decisions at the individual land user or household level. At the regional level, the role of human agency in land-use change patterns and processes was traditionally approached from an outside, regional scale perspective of aggregated human influence, such as changes in population density (Hersperger et al. 2010, Verburg 2014). When behavioral economics and psychological disciplines were integrated into the field of land-use science, microscaled approaches were incorporated to get an insider view of the systems, with questions such as "Why and how did the land user decide on this option?" (Moran 2010). A methodology to combine views on crop booms from both inside and outside, from the micro- and macroscales would shed light on how smallholders created the macrolevel phenomenon of crop booms with their land-use decisions.

Among disciplines studying decision making, there is largely consensus about the key role of the immediate context within which choices are made. According to Moran (2010) and Stern (2000), several psychological theories postulate that "environmentally relevant behavior lies at the end of a long causal chain of factors and the most notable key to behavioral change is the immediate context of behavior, and not deeply held values"(Moran 2010:40). Rather than looking in depth for cultural differences, we directed our attention toward immediate contexts and path dependency. For example, the immediate context could be the options available at the time and place of a decision and path dependency could come from earlier decisions and contexts that serve as the basis for today's decisions.

Capturing the diversity of contexts and histories of land-use decisions while scaling up and generalizing findings is challenging and resource intensive. Approaches that satisfy both needs are scarce. Synthesis methods such as meta-analysis of case studies are cost-effective and can contribute to the upscaling of findings on land-use decisions (Castella et al. 2012, Magliocca et al. 2015, van Vliet et al. 2015). However, time lags between the publication of a sufficient number of case studies and completion of the metaanalysis amounts to several years after which the crop boom may already be over. Furthermore, high heterogeneity in the quality and accuracy of context description in the literature underlying meta-analysis tends to diminish the explanatory value of local land-use decisions.

(Serious) games allow for much contextualization and are open to perspectives by participants that researchers might oversee as a result of predetermined research designs (D'Aquino et al. 2003, Castella et al. 2005). These games have become popular as a main ingredient for participatory research approaches (Barreteau et al. 2003). Like other participatory approaches, serious games can be used to engage and empower local communities (D'Aquino et al. 2003, Castella et al. 2014, Perrotton et al. 2017) or to elicit local knowledge and decision-making processes (Castella et al. 2005). However, because of this focus on context, games are rarely considered for synthesis purposes.

Our objective was to develop and apply a novel empirical approach for (1) gaining insight into the history and immediate contexts for the decisions of smallholders at the household and village level and (2) to synthesize these insights to the main factors at the regional, emergent level of the maize boom in northern Laos. Thereby, the method had to bridge multiple spatial scales and allow for the observation of a variety of contexts that influence farmers' decision making, i.e., socioeconomic, environmental, technical, economic, and, to some degree, cultural factors. We present a newly developed methodology that employs games to both understand the immediate context at the local level and to synthesize these contextual findings at the regional level.

\section{METHODOLOGY}

We developed a new approach called multiscale gaming that allows, on the one hand, the study of local, social-ecological contexts of land-use decisions, and, on the other hand, it provides a systematic procedure to scale up and generalize contextual findings toward the regional, emergent level of a large-scale landuse change process.

Serious games play a central role in this approach because of their flexibility and the fact that they can be designed for different purposes. They combine entertainment or playfulness with a more serious, problem-driven, and oftentimes educational purpose (Sawyer 2002, Voinov et al. 2016). Mediums and designs vary greatly because they range from fully computerized video games to analogue, or hybrid versions with, for example, a board game being coupled to an agent-based simulation model (Le Page et al. 2016). Klabbers (2009) discussed principles underlying games in depth and suggested that independent of the instrumentality of games, they, at the very minimum, "include actors, rules and resources" (Klabbers 2009:xv). However, there is no consensus on a single definition of serious games (Crookall 2010). Our entry point to games as a methodology stems from the companion modeling approach, which was developed to understand the complexity of social-ecological systems and to advance natural resource management (Barreteau et al. 2003, Bousquet et al. 2005, Campo et al. 2010). However, we harnessed serious games not only to explore dynamics within social-ecological systems 
Fig. 1. Multiscale gaming methodology. Systematic case study selection at the regional level is followed by field studies at the local level, which each represent different decision stages. Metagame represents the findings from the local level in a generalized form and can be validated in a serious game workshop with stakeholders.

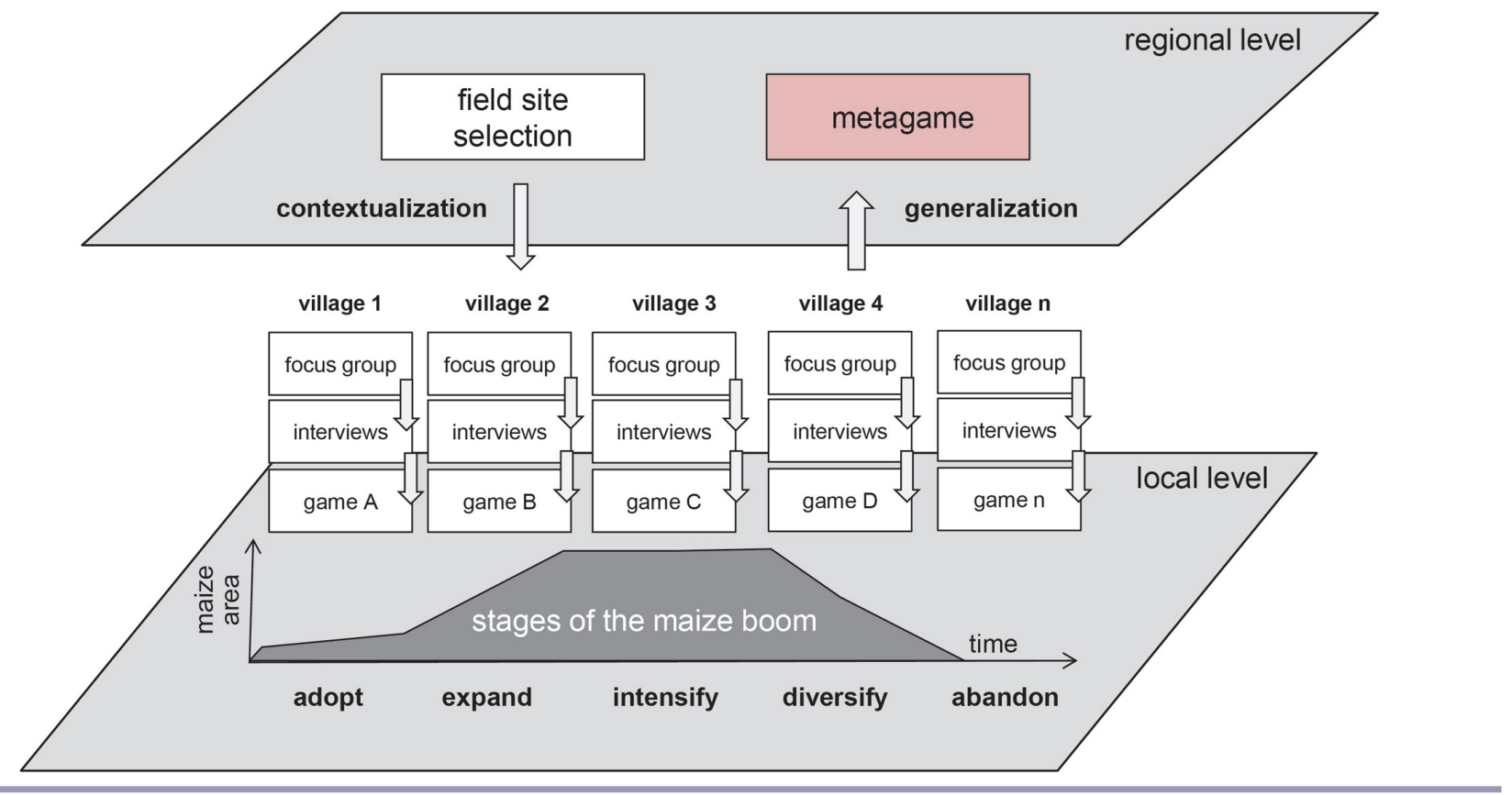

(Speelman et al. 2014), but also to generate and test hypotheses on land-use decision making (Anderies et al. 2011, García-Barrios et al. 2015). The serious games in this study were analogue, simplified versions of a land-use situation represented by tactile objects, rules, and roles. They were spatial (board games) or nonspatial (card games, role playing) and varied in the amount of variables (complicatedness) they represented. In essence, the serious games functioned as boundary objects between respondents and researchers and stimulated focused discussion of concrete land-use situations (Bourgoin et al. 2012).

\section{Overview of the multiscale gaming approach}

The approach is called multiscale gaming for brevity, but beyond games, it entails a sequence of methods that complement each other (Fig. 1). Starting with a view on the entire crop boom at the regional level, we selected a number of field sites that provided insights into each of the successive phases in the boom trajectory. Each phase corresponded to a specific land-use decision. Because crop booms are not happening simultaneously in all locations of a region, it is possible to study villages that are at the beginning, in the middle, or at the end of the maize boom.

At the local level, we carried out a series of methods that we refer to as field studies. In each site, we started with a focus group discussion with members of the village committee to reconstruct the village history related to hybrid maize. This initial, collective step was followed by interviews with several individual villagers about their household's history and current situation. Based on the information from the focus group and interviews, we defined one or two research questions to be explored for the respective village in a serious game or workshop element. Subsequently, the research team designed the games in situ within a few hours and held a serious gaming workshop to which we invited a socioeconomically diverse panel of farm households.

After completion of all the field studies, we designed a metagame that summarized our findings across all decision phases and local games. The building process of the metagame forced the research team to distill and formalize the common factors from the single villages' and households' narratives. The metagame session with experts as players served as an experimental space to test whether the observed and generalized narrative would let them create a maize boom with their decisions as well.

\section{Selection of case study villages}

The conditions and timing of the maize boom vary widely in northern Laos. In some places, diversification and abandonment had already been observed, whereas others had just passed the adoption phase during our field studies between November 2015 and January 2016. To study each of the five land-use phases, we tried to identify places in which those decisions were being made at the time of surveying. To help us find and select appropriate villages, we organized a participatory workshop with eight researchers from the Department of Agricultural Land Management (DALaM - Ministry of Agriculture and Forestry of Lao PDR) who worked with the EFICAS Project (Eco-Friendly Intensification and Climate resilient Agricultural Systems). They had a long work experience in 44 villages in the northern uplands of Laos. On a two-dimensional graph, the experts located the relative position of these villages along gradients of market accessibility and land degradation (see result in Appendix 1). Based on this initial assessment and by cross checking with the Lao agricultural census data 2011 (available at www.decide.la), the whole group of experts, including the authors, selected seven 
Table 1. Characteristics of selected villages.

\begin{tabular}{|c|c|c|c|c|c|c|}
\hline $\mathrm{Nr}^{\dagger}$ & Village & Province & District & $\begin{array}{l}\text { Agricultural } \\
\text { population }\end{array}$ & Ethnicity & Physical characteristics \\
\hline 1 & Houaykai & Louang Prabang & Vienkham & 387 & Khamu & upland, water scarcity \\
\hline 2 & Homephan & Houaphan & Houameuang & 495 & Khamu & upland \\
\hline 3 & Phoun-neua & Houaphan & Viengxai & 288 & Lao lum & upland \\
\hline 4 & Laeng & Xiengkhouang & Kham & 578 & Lao lum & plateau, moderate slopes \\
\hline 5 & Namen & Xiengkhouang & Nonghaet & 602 & Khamu & upland, water scarcity \\
\hline 6 & Mayphonexai & Sayabouri & Boten & 988 & Lao lum & plateau, moderate slopes, erosive soils \\
\hline 7 & Namgnang & Sayabouri & Paklai & 1281 & Lao lum & plateau, gentle slopes \\
\hline
\end{tabular}

villages that were expected to represent the different conditions and phases in the maize boom trajectory: Houaykai in Luang Prabang Province, Homephan and Phoun-neua in Houaphan Province, Laeng and Namen in Xiengkhouang Province, and Mayphonexai and Namgnang in Sayabouri Province. In Figure 2 , we locate these villages and we present further details and characteristics of the selected study sites in Table 1 .

Fig. 2. Location of selected case study sites for field survey (incl. local games) in northern Laos.

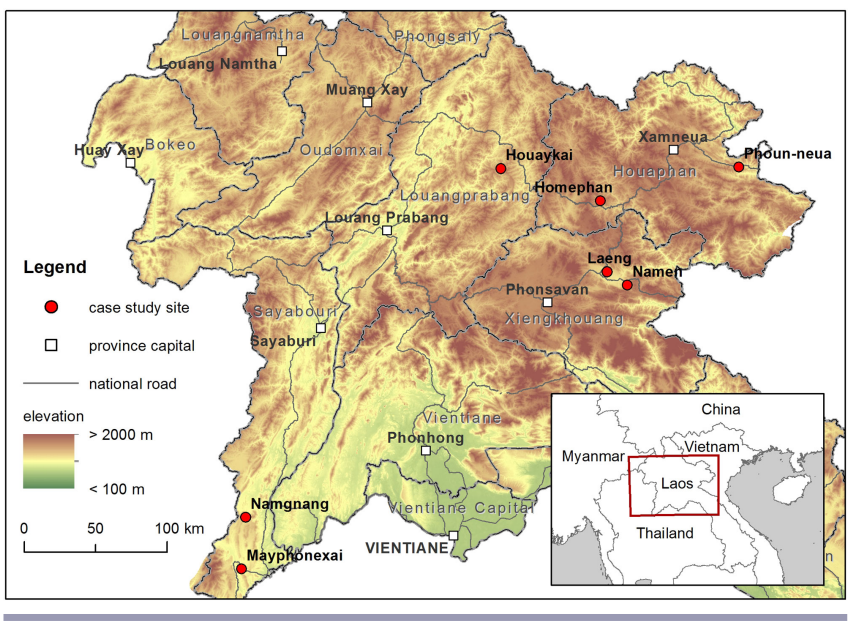

\section{Field studies}

In each of the seven villages, we used a sequence of three consecutive steps (Fig. 1). First, we conducted a focus group discussion with the village committee ( 7 to 10 persons depending on the village size) on the historical and current land use of the village. Second, we interviewed individual farmers on their household composition, production patterns, land-use history, their objectives and constraints, and how these parameters influence decision making. Third, we designed a serious game that specifically targeted the issues the research team prioritized based on results of the focus group and interviews. On the same evening or the day after, we applied the game as part of a participatory workshop with a group of household heads. To select a varied set of participants, we performed a principal component analysis (Pearson 1901, Wold et al. 1987) to capture each village's distinct diversity of wealth, forms of land use (not all had access to paddy or had dedicated livestock grazing areas), and age groups $(<30$ years, 30 until the mean age, mean age until oldest). Data from household surveys of the EFICAS project between 2011-2014 formed the basis for this analysis of three-four distinct farm types. From these farm types, we then randomly selected 12 farm household heads in total and invited them for the game workshop. In Laos, the heads of households are currently mostly male. An important part of the game were the debriefings, both collectively with all participants and individually through in-depth interviews of selected players. The field studies were carried out by a team of two researchers (first two authors of the paper), a native translator, a Lao agricultural technician, and a different district extension agent in each target district.

\section{Focus group discussions}

Focus group discussions served to reconstruct the village landuse history starting from the time when the farmers first grew hybrid maize. We invited the village committee and influential farmers, for example, those who pioneered with the crop. While facilitating the discussions, we documented and visualized the obtained information on posters to gradually enrich the overall picture and stimulate reactions from the participants.

The focus group discussions were used to verify/falsify the village's phase within the boom in relation to the hypothesis prevailing during the site selection. We also asked for information on the main crops (upland rice, paddy rice, maize, and other cash crops) such as area, production, yield, labor, input costs, and use of herbicides, fertilizers, and machinery. Land-use change, livestock dynamics, and other income generating activities (e.g., nontimber forest product collection, off-farm activities) were also investigated during the years 2000 to 2015 . This information was cross-checked with other sources of data such as qualitative individual interviews done later on, quantitative household surveys from the EFICAS Project, and secondary data from the district offices and Lao national agricultural census of 2011. We also asked about changes in prices and trading relations, access to credit, road construction, local policies, extreme weather events, and future aspirations of the community. During the discussions, participants brought up additional issues such as clogging of irrigation channels in paddy fields from soil erosion of maize fields, livestock diseases, damages to crops from freely roaming livestock, or the violation of contracts by traders. Overall, the focus group discussions helped the research team to prioritize the problems at hand and also to collect parameters for the local game. 


\section{Individual interviews}

The second step of the field studies consisted of interviewing three to five farmers to refine our understanding and the parameters gained from the focus group. This format served also to bypass social control effects that might have influenced group discussions. We tried, as much as possible, to include a diverse set of individual stories brought up by women and men who took part in the focus groups. We asked the village leaders and participants of the focus groups to direct us toward respondents who might add to the representativeness of our preselection based on the principal component analysis and connect us with representatives of the youth or the women's associations, pioneers in maize, or alternative land uses. During the semistructured interviews, we reconstructed the household trajectories with special emphasis on the household's demographic composition, land-use activities, income sources, and investments over the years. Furthermore, we asked follow-up questions when topics emerged during the interview such as increasing indebtedness. The interviews were directly translated and transcribed from Lao to English.

\section{Local serious games}

Based on the previous two steps, the team of researchers and local technicians specified questions regarding the situation of the village that could be explored in a serious game. Within a few hours up to one day, we developed a game that was specific to the village case. The materials for the games were designed and crafted by the team using simple artifacts such as posters with a grid to represent the space of the village, color cards to represent different land uses, tokens to represent people, labor force, or livestock, etc. The gaming sessions took two to four hours and included: (1) an introduction, (2) a few rounds of the game corresponding to cropping years or successive decisions, and (3) collective and individual debriefings to relate the game to the village's and individual participant's realities.

During the development of the methodology, we learned that the initial rounds are the most important to observe. When the same participants play the game several rounds, they develop more informed decision strategies. Because our main objective is to elucidate decision mechanisms as close as possible to reality in a crop boom (i.e., a situation of high uncertainty, high time pressure to seize opportunities, and poor understanding of the consequences of the decisions), we were only interested in the first few rounds of the games and, most importantly, in the player's comments and debates arising during these first rounds.

During the collective debriefing, we used elements of the game and posters on which we noted the individual and collective game results to ignite discussions on the choices made by participants during the gaming session. We brought in observations that we made before and during the game and asked for the participants' views and reasons for their decisions during the gaming sessions. The individual debriefings were carried out through semistructured interviews with three to four players, who came up with assertive ideas and behavior or interesting comments during the game. Immediately following the gaming session or the next day, we interviewed them at their houses, separate from the group to avoid a self-censorship effect. The interviews lasted one to two hours during which we assessed how the players understood the serious game and how their actions in the game related to their reality.

\section{The metagame}

After the field studies were complete, we aimed to bring all decisions along the maize boom trajectory into one metagame that contained and represented the essential findings from the field studies and the local games. The process of conceptualization, parameterization, and physical construction of the metagame was essential for us to formalize the knowledge we gained from the field studies into a consistent, testable framework. We then held sessions of the metagame with experts to share our understanding of the generalized system in a way that let the experts experience what it's like to be a farmer in the maize boom. These metagame sessions were also intended as an experimental validation of the concept behind the game, i.e., to see whether the experts' land-use decisions would cause a boombust land-use trajectory.

After a calibration test with university students from the Faculty of Environment of the National University of Laos, we played the metagame with six Lao agricultural experts of DALaM who each represented one farm household. To enrich the learning process, we invited four researchers from different disciplinary backgrounds as observers. The debriefing consisted of a collective round of discussions, interviews with the two experts who played most differently, and a short questionnaire that was filled in by the observers during and after the metagame.

\section{RESULTS}

\section{Field studies}

\section{Land-use trajectory, decisions, and their context}

Phoun-neua village has gone through the whole maize boom and bust (Fig. 3). The farmers adopted hybrid maize in 2008 when the first Vietnamese maize trader offered hybrid maize as an opportunity to generate income. This trader also provided credit to villagers for building a four kilometer-long "feeder" road with an excavator. Such roads are narrow, unpaved tracks dug on the hillsides and are just sufficient to reach remote areas of the village territory, with a tractor to till the land, trucks to bring the seeds and pick up the harvest, or motorcycles to bring people to work on the land. These roads feed maize expansion by improving the accessibility to land that was formerly used for shifting cultivation to grow upland rice. In 2009, the roads were built and the maize area and production had doubled. Production peaked in 2012, when a second feeder road was opened. Even though the villagers still expanded the maize area in 2013, the total production plummeted in that year because maize yields decreased in connection with soil erosion, weed infestation, and nutrient depletion after successive years of monocropping. In the following years, the maize area declined despite a steady upward trend of maize prices. Because farming practices are essentially manual (low degree of mechanization), household strategic choices are strongly related to labor requirements hence family composition. In a young family with newborn children, less area was cropped with maize, especially due to the efforts that manual weeding takes without the use of herbicides. The district authorities exerted strict regulations on maize cropping by prohibiting the use of herbicides and chemical fertilizers and allowing only one authorized trader. The trader they were assigned to was unreliable and uncooperative. These conditions further diminished the attractiveness of maize cropping and villagers had almost fully abandoned maize in 2015 . 
Fig. 3. History of hybrid maize cropping in Phoun-neua village. For comparability of different units, the changes of agroeconomic parameters are shown as a change index relative to the start of hybrid maize cropping in 2008.

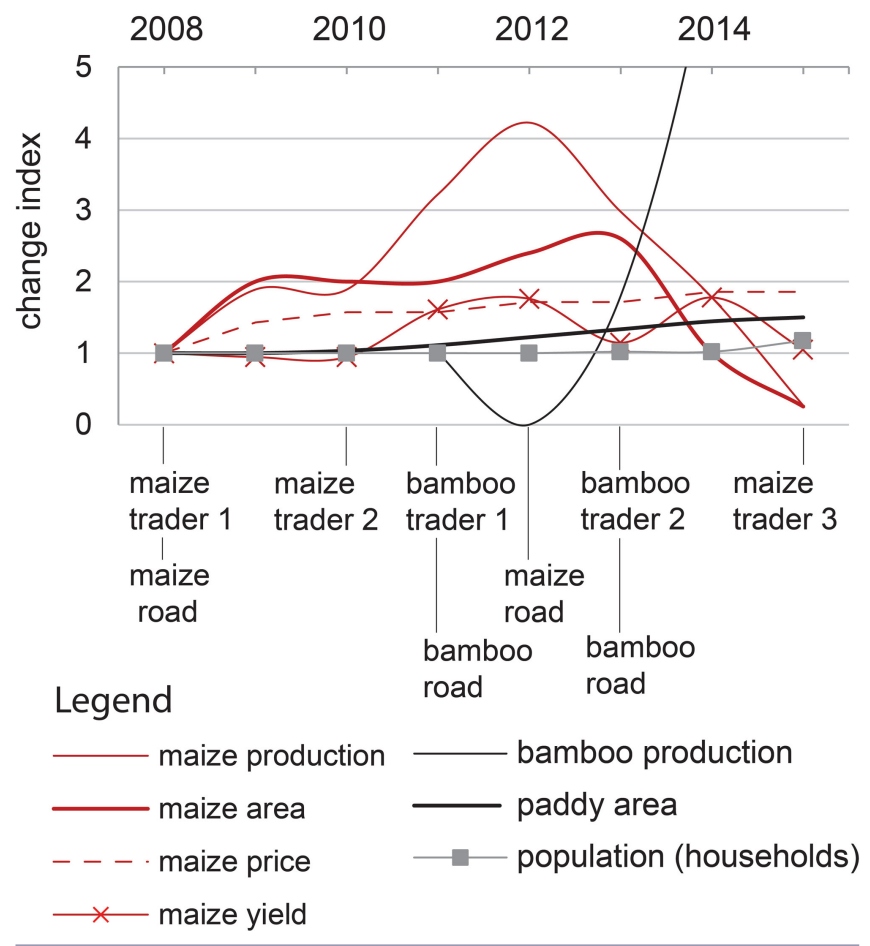

The bust phase of maize in Phoun-neua was accelerated by traders from Vietnam, who offered a new market opportunity for bamboo stems and shoots that had to be harvested from the community forests. Bamboo harvest fitted well with the agricultural calendar because it complemented labor requirement peaks for annual crops. The construction of additional feeder roads to bamboo forests was facilitated by credits provided by bamboo traders, and good prices were promised thanks to the support of an international NGO. As a result, bamboo collection rapidly skyrocketed until it was abruptly stopped by Prime Minister decree No. 15/PM dated 13 May 2016, which strictly banned the export of unprocessed forest products. From 2013, a few villagers expanded their paddy area when the opportunity to terrace individual paddy fields on credit was offered by a local entrepreneur, and village regulations were amended to make individual paddy area allocation possible. Other investments were reported to be directed at children's education, vehicle purchase, and most notably, at livestock systems.

Local serious games

Based on the village trajectory, we designed a serious game for Phoun-neua to explore what the farmers invest in after making profits from maize cropping. A description of the resulting game named MIALU, maize investments and alternative land uses, is given in Appendix 2. In the MIALU board game, a virtual village landscape is represented on a grid of $10 \times 10$ cells with a village center, protected forest area, forest fallow, and current upland and lowland land uses of Phoun-neua including upland rice, maize, and paddy rice. Twelve participants were invited to be players of six game households, i.e., two participants, belonging to different households in reality but with similar socioeconomic conditions, were assigned to a game household. The intention underlying this set-up was to make the decision-making process more easily observable for the research team, as each pair of players would be stimulated to discuss their thoughts aloud.

There were three different types of virtual farms to which we assigned the participants according to their real socioeconomic backgrounds as identified in the principal component analysis (family composition, wealth, farm activities). An initial land-use setting was provided with equal conditions for each farm type. The initial number of plots per household was determined by the area a household could manage with its available labor force. In each round, the participants decided how to manage their land and what to buy with the money they made. Before the start of the first round, we asked the participants to verify and complement the parameters about land uses and items available on the virtual market. New land uses or products in the incomeinvestment cycle were integrated into the MIALU game when brought up by the players, e.g., bamboo, feed for livestock, fishponds, teak, and fruit trees. Communication among participants was encouraged throughout the game. The facilitators and coplayers provided help in case of difficulties in understanding the game. We played two rounds of field allocation and three rounds of investment decisions.

In the first round of the MIALU game in Phoun-neua, the players searched for alternative land uses and income sources to maize cropping and had almost abandoned it fully by the second round. In the first round, four households invested in the education of their children, three chose to open new paddy fields or to expand existing ones and/or invested in livestock, while one bought fruit trees, and one purchased a motorbike. In the second round, several households chose to mechanize and increase mobility (e.g., hand tractors, threshing machine, motorbikes), two thirds invested in livestock, and one third invested in setting up off-farm activities, i.e., a small shop and weaving. In the third round, one household brought up the idea of digging a fishpond, another opened a savings account at the bank, and another household built a road to a newly opened paddy area.

After the game, participants discussed their specific decisions in relation to reality. Almost every player expanded paddy areas during the game, reflecting the recent trend of paddy terracing in Phoun-neua, with a $62 \%$ increase of 5.3 ha between 2012 and 2014 from the initial 8.5 ha. Furthermore, the money from cash crops was used for daily family expenses and children's education. As smallholders abandoned maize, they would also be willing to expand livestock farming in the uplands or adopt a new cash crop following the demand of the market. Individual players mentioned that they decided to invest in livestock, teak, and fruit trees given the decrease of available labor force as they advanced in the family cycle, i.e., ageing of household heads, children being away at school, or children creating their own households when adult.

Individual debriefings revealed that the farm households abandoned maize (in their real lives) due to both gradual yield decreases and the instability of the market outlet (i.e., delayed collection of harvest by traders and lower prices than promised 
Table 2. List of local serious games developed and applied in respective case study sites.

\begin{tabular}{|c|c|c|c|c|}
\hline $\begin{array}{l}\text { Short } \\
\text { name }\end{array}$ & Full name & Purpose & $\begin{array}{l}\text { Location of design } \\
\text { and application }\end{array}$ & $\begin{array}{l}\text { Decision phase at time of } \\
\text { survey }\end{array}$ \\
\hline$\overline{\text { MAPRI }}$ & Maize Allocation and PRices & $\begin{array}{l}\text { explore spatial maize allocation patterns and } \\
\text { reactions to price changes }\end{array}$ & Houaykai & adoption/expansion \\
\hline MIALU & $\begin{array}{l}\text { Maize Investments, Alternatives } \\
\text { and related Land Use changes }\end{array}$ & $\begin{array}{c}\text { explore investments from maize profits and } \\
\text { maize alternatives }\end{array}$ & $\begin{array}{l}\text { Homephan, } \\
\text { Phoun-neua, } \\
\text { Laeng }\end{array}$ & $\begin{array}{c}\text { expansion/intensification } \\
\text { abandonment } \\
\text { diversification }\end{array}$ \\
\hline MaRISK & Maize and RISK behavior & explore land-use related risk behavior and debts & Namen & $\begin{array}{c}\text { intensification/ } \\
\text { diversification }\end{array}$ \\
\hline PALUM & $\begin{array}{l}\text { Preferred Alternative Land Uses } \\
\text { to solve Maize problems }\end{array}$ & $\begin{array}{l}\text { explore preferences among proposed solutions } \\
\text { to maize problem }\end{array}$ & Namen & diversification \\
\hline MALAD & MAize and LAnd Degradation & $\begin{array}{c}\text { explore reactions to maize-induced land } \\
\text { degradation }\end{array}$ & Mayphonexai & diversification/abandonment \\
\hline TAKIT & $\begin{array}{l}\text { Take it! Factors for adopting } \\
\text { alternatives to maize }\end{array}$ & $\begin{array}{l}\text { explore the primary factors for adoption of an } \\
\text { alternative }\end{array}$ & Namgnang & diversification/abandonment \\
\hline
\end{tabular}

in the contract). Also, the hybrid maize seeds, which had to be bought every year, created a dependency on a particular trader, unlike with other crops. Moreover, Phoun-neua's farmers did not experience the labor-saving effect of tillage (slopes are too steep for a tractor to till) or herbicide (a ban is enforced by district authorities). Instead, villagers seized the rising bamboo growing opportunity as a replacement to hybrid maize, accelerating the abandonment phase of the village maize trajectory. The respondents claimed that their investment decisions in the game largely reflected their reality. They paid for their children's education, expanded paddy, and wished to take on new cash crops and expand livestock activities. Reinvestments of profits from maize to paddy terracing were explained by respondents as a way to secure land rights and rice self-sufficiency. Furthermore, they obtained better returns on labor and land with rain-fed lowland rice than with upland rice from shifting cultivation.

Addressing similar research questions to Phoun-neua, we also used the principle design of MIALU in Homephan and Laeng villages. In addition, five local games of different natures, addressing different land-use decisions along the maize boom and bust trajectory were designed and applied in the remaining four villages (Table 2). Detailed descriptions of the local games are available in Appendix 2.

\section{The metagame}

The concept underlying the metagame is a result of the synthesis process of the field studies. To build the metagame, we distilled the essence of what we observed in all field studies and arrived at a set of six overarching factors that influenced the land-use decisions from a farmer's perspective. The variation of these factors over time forms the conceptual basis for the design of the metagame (Fig.4). The metagame, named mahasaly, Lao translation for higher level (maha) maize (saly), represents the research team's understanding of how the maize boom emerged from smallholders' individual decision making.

\section{Factors influencing land-use decisions}

Based on findings from the field studies, we formed the following generalizations about farmers' motivations, attitudes, behaviors, and perceptions. First, the underlying motivation in all stages of the boom is to maintain and improve family well-being in the short and long term. Second, most farmers react to opportunities they perceive and compare them to the available alternatives. Third, risk regarding crop yields, livestock diseases, market prices, and trader's reliability is omnipresent in farming. Risk avoidance or inversely, the search for stability and security is a key attitude. Fourth, farmers' perception of the availability of suitable land for maize cropping may stimulate or withhold strategic land-use decisions. Fifth, interactions between farmers take place in the form of imitation and less like an active coordination, negotiation, or collaboration. Farmers reported to hardly gathering to exchange information or to set up collective, concerted action, e.g., to address that soil erosion from upland maize fields causes siltation of irrigation channels in rice paddies (Namen village). We did observe some elements of consultation both in the local games and real life. Where Lao Lum ethnicities prevailed, farmers coordinated to improve livestock management and prevent free roaming animals from eating cultivated crops. However, imitation behavior has been both reported by participants themselves and observed in local games, focus groups, and interviews multiple times, and we suspect that this may be the most common way of interacting. The economic factors (including perceived opportunities and risks) largely prevail over the cultural ones in influencing the successive decisions along the maize trajectories.

In line with these generalizations, six factors crystallized based on the findings from the field studies. The sequence of factor combinations over time constitutes the narrative we distilled and illustrates the changing contexts regarding maize cropping from the perspective of farmers (Fig. 4). First and foremost, the existence of a market outlet was put forward by many respondents as the key factor to their decision to adopt the new cash crop. Many respondents expressed this as: "we can produce anything provided there is a market for it!" Farmers from Phounnoua and Houaykai regions, for example, explained that they do not grow certain crops (e.g., soybean) "because no trader asked for it." Second, trust in the trader's reliability and the market stability of a commodity is of high interest to the farmers, i.e., low price fluctuations when supply increases (a key finding from TAKIT game). In Namgnang, for example, farmers had recently adopted Job's tears' crop (Coix lacryma-jobi), another cereal boom crop used generally for food, drinks, and medicinal or ornamental purposes. The area cropped with Job's tears was not 
Fig. 4. Factor combinations that build the context for farmer's decisions in the maize boom and bust. This is the narrative/conceptual model underlying the metagame mahasaly. Solid line $=$ factor present; dashed line $=$ factor may or may not be present yet/anymore.

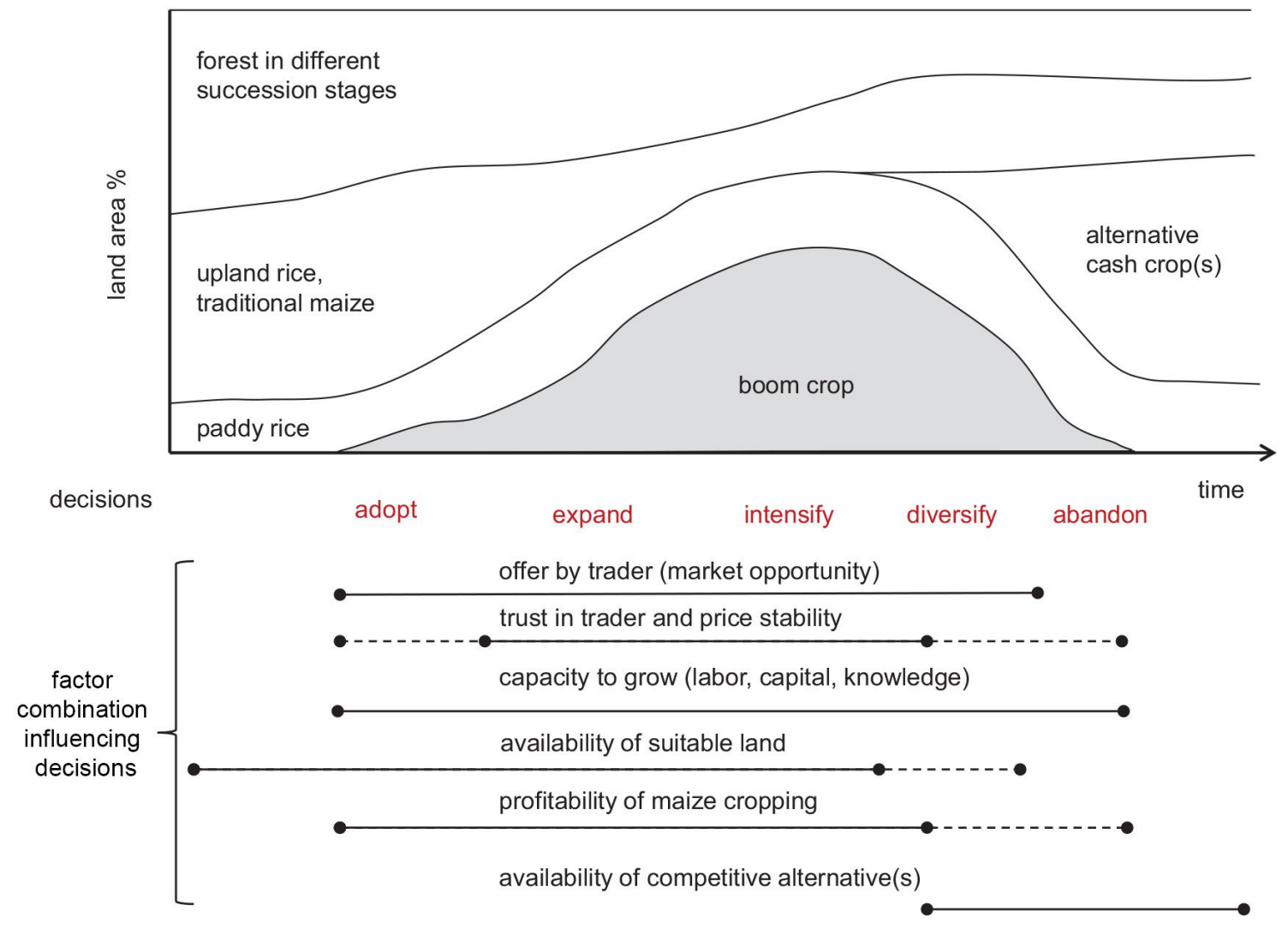

expanded because the prices fluctuated too much, according to the farmers. Third, feasibility is a cumulative term for the farmer's ability to grow a crop with respect to labor and mechanization requirements, knowledge on the crop's needs and growth process, financial input, and accessibility of fields. For example, several players mentioned their old age and too little labor capacity as reasons against certain land uses. Fourth, land quantity and quality involve access to sufficient suitable land. It is separated from the other farm household's feasibility variables because land scarcity can trigger intensification (because there is too little land to expand into, the available land is used more intensively to meet the demand), even if there is still enough labor capacity to expand maize cropping. The lack of sufficient suitable land is also a consequence of intensive maize cropping, which quickly degrades soil. Land degradation becomes an essential factor that contributes to diversification and abandonment decisions. Fifth, the expected profitability (net revenue) of the boom crop depends on maize price, on crop yield, and on input costs (seeds, herbicide) or reimbursement of credits. Sixth, the availability of a competitive alternative can change the view on a boom crop entirely. It can prevent a boom and cause early diversification or facilitate the bust and make a shift away from maize possible (e.g., TAKIT game in Namgnang and bamboo as an alternative to maize in Phoun-noua). In turn, the lack of a competitive alternative can cause a prolongation of the boom despite the farmer's willingness to abandon maize or diversify. Individual debriefings in Homephan, Laeng, and Namgnang revealed that farmers wished to stop with maize because they perceived the adverse effects on their land. However, they saw no real alternative income that could support their families.

\section{The metagame session}

The metagame mahasaly incorporates elements of structure, parameters, and lessons from the six local games presented in Table 2 and Appendix 2. We provide a detailed description of the rationales for the development of the metagame and a brief description of its rules in Appendix 3.

When the experts took on the role of farmers in the mahasaly game workshop, their decisions in the game resulted in land-use changes that cumulated in a typical boom and bust shape (Fig. 5). In the metagame, the factors that are relevant for the player's decisions (e.g., the set of available land-use options) varied over time according to the generalized narrative (Fig. 4). Hence, our understanding of the key decisions in the boom trajectory was confirmed. Maize was adopted as soon as the opportunity arose on the market: five out of six players immediately engaged in maize cultivation with at least one plot of maize in the following year without knowing about the stability of the market. The expansion phase followed, albeit at a moderate pace and 
Fig. 5. Results of the mahasaly metagame session with experts. The top graph shows the cumulative land-use changes of all players, whereas the bottom graph displays the spatial changes on the game board. How game facilitators changed the conditions for all players (e.g., arrival of different traders) is indicated with each round (compare with Fig. 4).

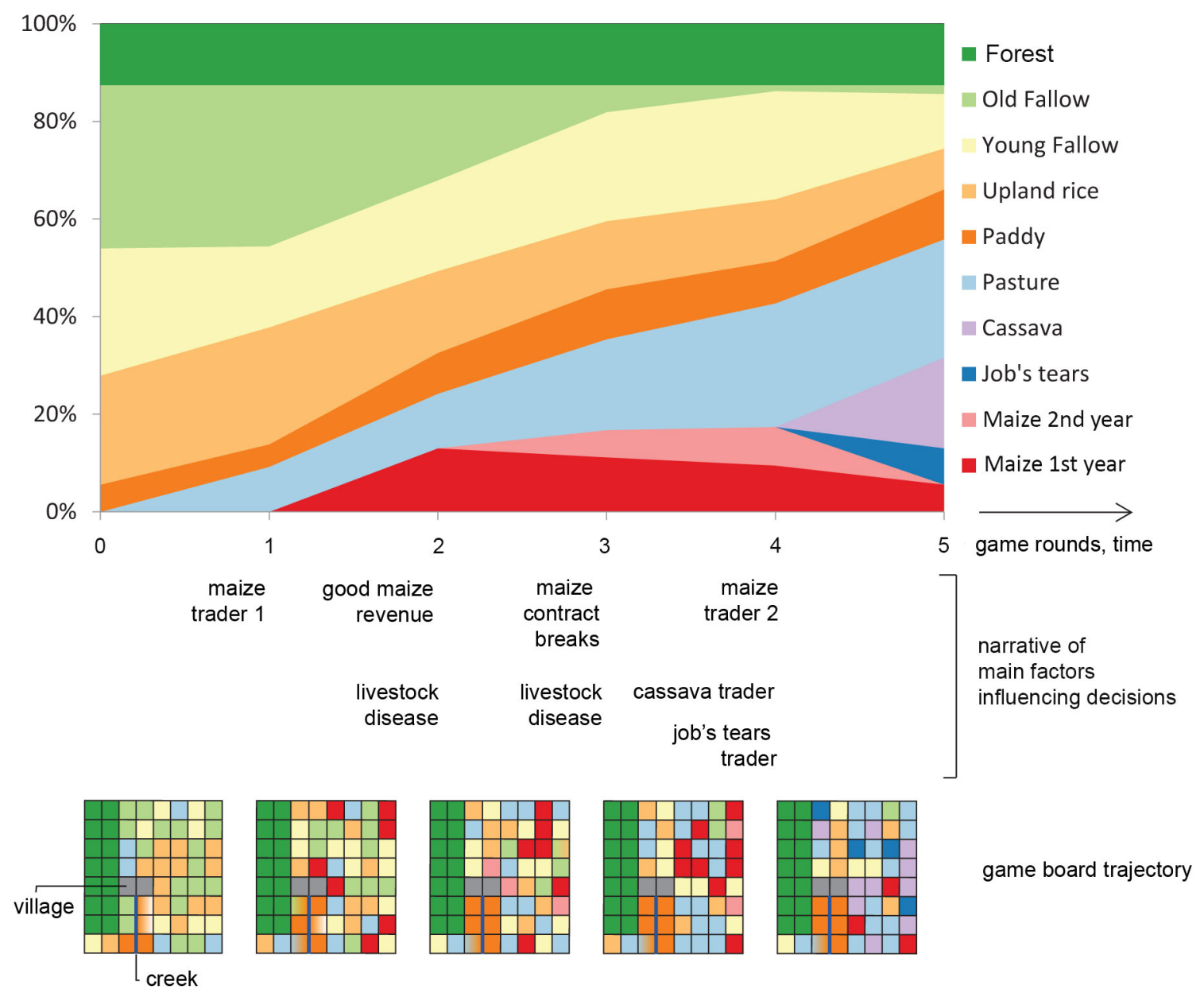

magnitude. Revenues from the first round were invested into paddy terracing. Many players kept on investing in livestockpasture despite two disease outbreaks. A poor game household without paddy continued with upland rice because, for the player. maize was too input intensive (factor feasibility) and connected with adverse effects. The expert playing this household recalled memories from the experiences in his own province (Sayabouri). Intensification did not occur during the metagame because there was still much fallow land available. Participants could have selected intensive cropping systems, but, as they were not constrained by land scarcity, they felt intensification was more risky than diversifying. This reflects the reality of Lao uplands, in which lower population density and less agricultural pressure than in neighboring countries prevails. The participant's priority of diversification over intensification between rounds four and five was also a response to (1) contract breaking by the maize trader, (2) appearance of cassava and Job's tears as two new competitive alternatives, and (3) interest in livestock-pasture as another strong alternative. Throughout the whole metagame, the players diversified their land-use portfolio, leading to a gradual decrease in maize areas.

\section{DISCUSSION}

Advantages and constraints of a multiscale gaming approach

The approach we developed and applied in this study meets two challenges that are very common in social-ecological systems research. The first challenge is to capture contexts of farmer household decision making in real-time and place. The second challenge is to generalize across these contexts and identify the most relevant factors influencing the decision makers over time at the emergent level of the system (Janssen and Ostrom 2006). The multiscale gaming methodology provides the research design needed to explore contexts (field studies, local games) as well as generalize and test the knowledge gained (metagame).

The novelty of the methodology is based on three components. First, there must be a careful selection of case study sites, which are expected to represent the successive stages of the maize boom trajectory. This is a prerequisite to later be able to generalize local contexts. The second component is the use of serious games for each decision phase within the maize boom. They are adapted to the local context on the basis of focus group discussions and individual interviews, which provide insight into the village 
history and diverse household trajectories, respectively. The third component is a metagame that summarizes, generalizes, and tests the knowledge on contextualized decision behaviors over all decision phases from adoption until abandonment.

Conventional methods to empirically study land-use decisions at the household level include questionnaire surveys, laboratory and field experiments, or case studies that test a certain theory (Janssen and Ostrom 2006). Furthermore, meta-analyses are synthesis methods for uncovering insights over larger regions and/or specific land-change processes (van Vliet et al. 2015, Hettig et al. 2016). The multiscale methodology offers several advantages over these methods. First, it covers a sequence of decisions that influence each other and are path dependent. In a recent metastudy, Hettig et al. (2016) found that most studies investigating household decision making in the tropics only covered one decision situation in isolation. Multiscale gaming offers new opportunities to take path dependency and a whole narrative of decision making into account. Second, the methodology is flexible to the context of each site. Hence, all questions, topics, and factors that are relevant at the moment and location of the study can be considered if they are raised by the respondents or observed by the research team. In more rigid methods, such as questionnaires and experiments, the questions have to be formulated beforehand to guarantee comparability for statistical testing. Third, the approach asks for participation and validation by the respondents in the games of the field study and the metagame. Fourth, the multiscale gaming approach does not control for or reduce context like in experiments; rather, it tries to be open to capture diversity and combination of contextual factors. Fifth, the multiscale gaming approach is fast. We arrived at synthesized knowledge within half a year, whereas the research process from case studies to synthesis in metastudies takes up several years or decades before sufficient material is available from the literature to conduct a systematic review. Sixth, it provides researchers with the opportunity to share their system understanding with stakeholders in an experiential way. Concrete experiences are made by the players, observations are reflected upon, and active experimentation on abstract concepts, such as the maize boom, becomes possible (Dieleman and Huisingh 2006). Finally, games make it possible to formalize mental models (Anderies et al. 2011). The multiscale gaming method operationalizes the mental model of the researchers by forcing them, during the design of the metagame, to make their understanding of the links, causes, and effects within the system explicit. They need to represent their system knowledge by defining concrete roles, relations of different prices or resources, and a clear narrative. Thereby, the metagame encapsulates both qualitative and quantitative research findings and serves interdisciplinary research efforts. The game sessions, and especially the debriefings, allowed the players to validate or correct the researcher's system understanding. Consequently, the games are built-in instruments of validation.

As with other methods, the multiscale gaming approach is also subject to a number of constraints. The number of people who can attend a game session is limited. Therefore statistical tests on the results of single sessions are hardly meaningful because the sample size of players per session is too small. More in-depth discussion of the strengths and weaknesses of serious games as a methodology is provided by other authors (Barreteau et al. 2003,
D'aquino et al. 2003, Étienne 2011, Speelman et al. 2014, Le Page et al. 2016, Perrotton et al. 2017). Our selection of household interviewees was intended to be representative of the diversity of livelihoods. For practical reasons and availability of interviewees, this could not always be fulfilled. We recommend that researchers pay attention to this point in further applications of this method. Furthermore, our approach is not suited for an in-depth analysis of cultural dimensions such as deeply held values or gender differences. Although the villages selected for this study represent a diversity of ethnic groups (cf. table 1), we did not find strong evidence that the ethnic background limited or enabled a decision to the same extent as the availability of a market opportunity (contract farming offered by a trader) did. Even if we would have found evidence for cultural differences, the research design for this study's objective (different decision phases) does not provide firm grounds for conclusions about cultural aspects because this would have required a research design in which different ethnicities could be compared within the same decision phase. Nevertheless, during the course of the field studies, we did ask a few probing questions on women's roles in household decision making. Respondents reported that strategic decisions like those in the maize boom are usually discussed between the couple.

The multiscale gaming approach contains several participatory elements that are inspired by and belong to the methodological family of rapid rural appraisals (RRA) and participatory rural appraisals (PRA). Following the classification by Chambers (1994), the multiscale gaming approach is a form of rapid rural appraisal; our goal was to elicit knowledge rather than facilitate change. In the context of this study, we (the researchers) aimed to learn about the system dynamics rather than to empower the local people. A sharp distinction is difficult to make because spillover effects and empowerment may have occurred. However, it is important to note that we did not intend to facilitate change, but to acquire knowledge about the system dynamics that can further be used to codesign interventions toward sustainable land use.

\section{Main lessons}

Environmental trade-offs for long-term goals

Cropping maize on steep slopes and erosive soils over the course of 10 to 15 years had a substantial impact on forest cover and land degradation of a large part of northern Laos (Lestrelin 2010, Lestrelin and Castella 2011). In this context, scientists consider intensive maize monocropping to be an ecologically exploitive land use that only yields short-term benefits. Our results suggest that farmers invest these short-term benefits on the cost of ecologic sustainability into long-term goals regarding their livelihoods, including education, housing, mobility, farm mechanization, and livestock purchases. Further, they secure access and rights to land through road building and paddy terracing. They also invest capital gained from maize cropping into off-farm activities like buying trucks to gain income from transportation and trading services. Land degradation is recognized by farmers in their real-life situations, but often not acted upon because other necessities for livelihoods outweigh ecological concerns. These kinds of trade-offs have also been reported for mountainous farming environments in Europe, where farmers intended to support ecosystem functioning, but other, more influential factors (feasibility, profitability) overruled 
their concerns for environmental degradation (Lamarque et al. 2014). Findings of local games and interviews in our study suggest that the continued exploitation of land is seen as a bridging strategy until other competitive alternatives become available or feasible. This is especially the case during times when the household is in need of stability, for example when the farmer's children are still at a crucial education phase.

\section{Risk buffering and household life cycle}

More generally, our findings about risk aversion in land-use decisions depending on household composition conform to Chayanov's model of the household life cycle (HHLC). The HHLC model was developed and applied to areas with similar conditions to northern Laos in terms of (initially) relatively abundant land resources, few market opportunities, and a basic, but evolving road network (Walker et al. 2002 after Goody 1958 and Chayanov 1925, 1966). According to the HHLC model, demographic composition of a farm household plays a central role in land-use decisions at different stages of the household cycle, as it progresses from a nuclear to multigenerational structure. In the nuclear stage, the model assumes high-risk aversion to capital intense investments because of a high dependency ratio (several consuming family members supported by few labor units). Hence, annual cropping is favored. In later household stages, lower-risk aversion is assumed because of an increase in the number of labor units and available capital. This favors reinvestment of profits in perennial cropping and livestock ranching. In line with this, elderly participants in several of our local games opted for tree crops, pasture, and/or invested in livestock. They argued that their reasons were to prepare for their own evanescent labor force while securing their livelihood. Often, they did not expect their children to contribute to the household's farming activities in the longer term because they supposed the next generation would migrate to urban centers thanks to higher education.

Emergence of a maize boom in the metagame and in reality In the metagame with experts as well as in the local games with farmers, we found a variety of land-use trajectories that were largely shaped by differences in risk taking and, to a certain degree, by differences in household wealth. At the same time, the shape of the boom could be identified at the village level in local games and surveys. This highlights the cumulative effect of individual behaviors. Observers of the metagame noted the lack of interaction between the players during the mahasaly game. We postulate that interactions did take place, but not in the form of active collaboration, coordination, or negotiation. Instead, based on our observations in the field studies and metagame, we posit that imitation of influential farmers or coplayers, respectively, is a passive form of interaction that contributes to the speed of the boom and bust phases. The degree to which social factors like imitation or coordination influences the speed and outcome of the land-use change process remains to be investigated.

\section{CONCLUSIONS}

The multiscale gaming approach developed in this study is a tool to elicit, generalize, and share insights from local, microlevel, land-use trajectories (i.e., household, village) and their impacts on regional, macrolevel, social-ecological system dynamics. Beyond this, repeated metagame sessions could be used as a learning tool for stakeholders to go through the experiential cycle of the maize boom and bust. The participants of a metagame session would learn by doing without the large environmental and socioeconomic losses that a maize boom can cost in reality. Extension agents who advise and inform farmers in their decision making would benefit from such gaming sessions. Moreover, the metagame is a tool for researchers to organize, share, and validate their knowledge through interactions with other stakeholder groups such as policymakers.

Our study suggests that the timing of competitive alternative land uses can bifurcate unsustainable trajectories and lead to land-use diversification. To inform strategic land-use decisions in boomprone areas, we suggest assessing (1) the full set of available landuse options perceived by affected farmers, (2) the perceived feasibility, and (3) the perceived profitability of each option. Finally, imitation behaviors as the prevalent (but not only) form of interaction in the decision-making processes should receive more attention in land-use planning, development programs, and research agendas. To learn how a crop boom could be avoided, the metagame could help to explore the effects of alternative individual behaviors at the microlevel or alternative policies and intervention mechanisms at the macrolevel.

\section{Responses to this article can be read online at: http://www.ecologyandsociety.org/issues/responses. php/10104}

\section{Acknowledgments:}

Support for the research was provided by the European Union's Seventh Framework Programme ERC Grant Agreement $n r$. 311819 - GLOLAND and the Global Climate Change Alliance (EFICAS Project). Support from the Agence Française de Développement (AFD) was also granted under the NUDP-CA Project. We acknowledge the Department for Agricultural Land Management DALAM and CIRAD Laos as key partners in the field survey and thank all participants and assisting facilitators for their contributions.

\section{LITERATURE CITED}

Anderies, J. M., M. A. Janssen, F. Bousquet, J.-C. Cardenas, D. Castillo, M.-C. Lopez, R. Tobias, B. Vollan, and A. Wutich. 2011. The challenge of understanding decisions in experimental studies of common pool resource governance. Ecological Economics 70 (9):1571-1579. http://dx.doi.org/10.1016/j.ecolecon.2011.01.011

Barreteau, O., C. Le Page, and P. D'aquino. 2003. Role-playing games, models and negotiation processes. Journal of Artificial Societies and Social Simulation 6(2):1-10. [online] URL: http:// jasss.soc.surrey.ac.uk/6/2/10.html

Bousquet, E. F., G. Trébuil, and B. Hardy. 2005. Companion modeling and multi-agent systems for integrated natural resource management in Asia. International Rice Research Institute (IRRI), Los Banos, Philippines. [online] URL: http://cormas. cirad.fr/pdf/AsiaBook/all.pdf

Bourgoin, J., J.-C. Castella, D. Pullar, G. Lestrelin, and B. Bouahom. 2012. Toward a land zoning negotiation support 
platform: "tips and tricks" for participatory land use planning in Laos. Landscape and Urban Planning 104(2):270-278. http://dx. doi.org/10.1016/j.landurbplan.2011.11.008

Byerlee, D. 2014. The fall and rise again of plantations in tropical Asia: history repeated? Land 3(3):574-597. http://dx.doi. org/10.3390/land3030574

Campo, P. C., F. Bousquet, and T. R. Villanueva. 2010. Modelling with stakeholders within a development project. Environmental Modelling and Software 25(11):1302-1321. http://dx.doi. org/10.1016/j.envsoft.2010.01.005

Castella, J.-C. 2012. Agrarian transition and farming system dynamics in the uplands of South-East Asia. Pages 1-20 in Proceedings of the $3 \mathrm{rd}$ international conference on conservation agriculture in Southeast Asia: conservation agriculture and sustainable upland livelihoods. Innovations for, with and by farmers to adapt to local and global changes. CIRAD, Montpellier, France; Northern Mountainous Agriculture and Forestry Science Institute (NOMAFSI), Phu Tho, Vietnam; University of Queensland, Centre for Communication and Social Change, School for Journalism and Communication, Brisbane, Australia. [online] URL: http://horizon.documentation.ird.fr/exl-doc/pleins textes/ divers13-06/010058352.pdf

Castella, J.-C., J. Bourgoin, G. Lestrelin, and B. Bouahom. 2014. A model of the science-practice-policy interface in participatory land-use planning: lessons from Laos. Landscape Ecology 29 (6):1095-1107. http://dx.doi.org/10.1007/s10980-014-0043-x

Castella, J.-C., G. Lestrelin, and P. Buchheit. 2012. Agrarian transition in the northern uplands of Lao PDR: a meta-analysis of changes in landscapes and livelihoods. Pages 40-44 in Proceedings of the $3 r d$ international conference on conservation agriculture in Southeast Asia: conservation agriculture and sustainable upland livelihoods. Innovations for, with and by farmers to adapt to local and global changes. CIRAD, Montpellier, France; Northern Mountainous Agriculture and Forestry Science Institute (NOMAFSI), Phu Tho, Vietnam; University of Queensland, Centre for Communication and Social Change, School for Journalism and Communication, Brisbane, Australia. [online] URL: http://horizon.documentation.ird.fr/exl-doc/pleins textes/ divers13-06/010058353.pdf

Castella, J.-C., T. N. Trung, and S. Boissau. 2005. Participatory simulation of land-use changes in the northern mountains of Vietnam: the combined use of an agent-based model, a roleplaying game, and a geographic information system. Ecology and Society 10(1):27. http://dx.doi.org/10.5751/ES-01328-100127

Chambers, R. 1994. The origins and practice of participatory rural appraisal. World Development 22(7):953-969. http://dx.doi. org/10.1016/0305-750X(94)90141-4

Cramb, R., V. Manivong, J. C. Newby, K. Sothorn, and P. S. Sibat. 2017. Alternatives to land grabbing: exploring conditions for smallholder inclusion in agricultural commodity chains in Southeast Asia. Journal of Peasant Studies 44(4):939-967. http:// dx.doi.org/10.1080/03066150.2016.1242482

Crookall, D. 2010. Serious games, debriefing, and simulation/ faming as a discipline. Simulation and Gaming 41(6):898-920. http://dx.doi.org/10.1177/1046878110390784
D’Aquino, P., C. Le Page, F. Bousquet, and A. Bah. 2003. Using self-designed role-playing games and a multi-agent system to empower a local decision-making process for land use management: the selfCormas experiment in Senegal. Journal of Artificial Societies and Social Simulation 6(3). [online] URL: http://jasss.soc.surrey.ac.uk/6/3/5.html

De Koninck, R. 2004. The challenges of the agrarian transition in Southeast Asia. Labour, Capital and Society 37:285-288.

Dieleman, H., and D. Huisingh. 2006. Games by which to learn and teach about sustainable development: exploring the relevance of games and experiential learning for sustainability. Journal of Cleaner Production 14(9-11):837-847. http://dx.doi.org/10.1016/ j.jclepro.2005.11.031

Étienne, M. 2011. Companion modelling: a participatory approach to support sustainable development. Quae, Versailles, France.

Fox, J., and J.-C. Castella. 2013. Expansion of rubber (Hevea brasiliensis) in mainland Southeast Asia: what are the prospects for smallholders? Journal of Peasant Studies 40(1):155-170. http:// dx.doi.org/10.1080/03066150.2012.750605

García-Barrios, L., R. García-Barrios, J. Cruz-Morales, and J. A. Smith. 2015. When death approaches: reverting or exploiting emergent inequity in a complex land-use table-board game. Ecology 20(2):13. http://dx.doi.org/10.5751/ES-07372-200213

Hall, D. 2011. Land grabs, land control, and Southeast Asian crop booms. Journal of Peasant Studies 38(4):837-857. http://dx. doi.org/10.1080/03066150.2011.607706

Heinimann, A., and P. Messerli. 2013. Coping with a land-grab world: lessons from Laos. Global Change (80):12-15. [online] URL: http://www.igbp.net/news/features/features/

copingwithalandgrabworldlessonsfromlaos.5.19895cff13e9f675e252ba. $\underline{\mathrm{html}}$

Hersperger, A. M., M.-P. Gennaio, P. H. Verburg, and M. Bürgi. 2010. Linking land change with driving forces and actors: four conceptual models. Ecology and Society 15(4):1. http://dx.doi. org/10.5751/ES-03562-150401

Hettig, E., J. Lay, and K. Sipangule. 2016. Drivers of households' land-use decisions: a critical review of micro-level studies in tropical regions. Land 5(4):32. http://dx.doi.org/10.3390/ land5040032

Hirsch, P., and N. Scurrah. 2015. The political economy of land governance in the Mekong Region: contexts of policy advocacy. Pages 1-18 in Land grabbing, conflict and agrarian-environmental transformations: perspectives from East and Southeast Asia: an international academic conference. BRICS Initiatives for Critical Agrarian Studies (BICAS), Amsterdam, The Netherlands; MOSAIC Research Project, New York, New York, USA; Land Deal Politics Initiative (LDPI), Bellville, South Africa; RCSD Chiang Mai University, Chiang Mai, Thailand; and Transnational Institute, Amsterdam, The Netherlands. [online] URL: https://www.iss.nl/sites/corporate/files/CMCP_48-Hirsch_Scurrah. pdf

Janssen, M. A., and E. Ostrom. 2006. Empirically based, agentbased models. Ecology and Society 11(2):37. http://dx.doi. org/10.5751/ES-01861-110237 
Klabbers, J. H. P. 2009. The magic circle: principles of gaming and simulation. Third edition. Sense, Rotterdam, The Netherlands. [online] URL: https://www.sensepublishers.com/media/1107-themagic-circle-principles-of-gaming-simulation.pdf

Kugelman, M. 2013. The global farmland rush. New York Times, 5 February. [online] URL: https://www.nytimes.com/2013/02/06/ opinion/the-global-farmland-rush.html

Lamarque, P., P. Meyfroidt, B. Nettier, and S. Lavorel. 2014. How ecosystem services knowledge and values influence farmers' decision-making. PloS ONE 9(9):16. http://dx.doi.org/10.1371/ journal.pone. 0107572

Le Page, C., A. Dray, P. Perez, and C. Garcia. 2016. Exploring how knowledge and communication influence natural resources management With REHAB. Simulation and Gaming 47 (2):257-284. http://dx.doi.org/10.1177/1046878116632900

Lestrelin, G. 2010. Land degradation in the Lao PDR: discourses and policy. Land Use Policy 27(2):424-439. http://dx.doi. org/10.1016/j.landusepol.2009.06.005

Lestrelin, G., and J.-C. Castella. 2011. Opportunities and challenges for the adoption of conservation agriculture in maize production areas of Laos. in 5th world congress of conservation agriculture incorporating 3rd farming systems design conference. Grains Research and Development Corporation (GRDC) and the Australian Centre for International Agricultural Research (ACIAR), Brisbane, Australia. [online] URL: http://aciar.gov.au/ files/node/13992/opportunities and challenges for the adoption of c 49307.pdf

Lund, C. 2011. Fragmented sovereignty: land reform and dispossession in Laos. Journal of Peasant Studies 38(4):885-905. http://dx.doi.org/10.1080/03066150.2011.607709

Magliocca, N. R., J. van Vliet, C. Brown, T. P. Evans, T. Houet, P. Messerli, J. P. Messina, K. A. Nicholas, C. Ornetsmüller, J. Sagebiel, V. Schweizer, P. H. Verburg, and Q. Yu. 2015. From meta-studies to modeling: using synthesis knowledge to build broadly applicable process-based land change models. Environmental Modelling amd Software 72:10-20. http://dx.doi. org/10.1016/j.envsoft.2015.06.009

Messerli, P., C. Bader, C. Hett, M. Epprecht, and A. Heinimann. 2015. Towards a spatial understanding of trade-offs in sustainable development: a meso-scale analysis of the nexus between land use, poverty, and environment in the Lao PDR. PLOS ONE 10 (7):1-18. http://dx.doi.org/10.1371/journal.pone.0133418

Moran, E. F. 2010. Environmental social science: humanenvironment interactions and sustainability. John Wiley and Sons, Chichester, UK. http://dx.doi.org/10.1002/9781444319057

Müller, D., Z. Sun, T. Vongvisouk, D. Pflugmacher, J. Xu, and O. Mertz. 2014. Regime shifts limit the predictability of land-system change. Global Environmental Change 28:75-83. http://dx.doi. org/10.1016/j.gloenvcha.2014.06.003

Pearson, K. 1901. On lines and planes of closest fit to systems of points in space. Philosophical Magazine 2(11):559-572. [online] URL: http://stat.smmu.edu.cn/history/pearson1901.pdf

Perrotton, A., M. de Garine-Wichatitsky, H. Valls-Fox, and C. Le Page. 2017. My cattle and your park: codesigning a role-playing game with rural communities to promote multistakeholder dialogue at the edge of protected areas. Ecology and Society 22 (1):35. http://dx.doi.org/10.5751/ES-08962-220135

Rigg, J., and P. Vandergeest, editors. 2011. Revisiting rural places: pathways to poverty and prosperity in Southeast Asia (challenges of the agrarian transition in Southeast Asia). NUS Press, Singapore.

Rulli, M. C., A. Saviori, and P. D’Odorico. 2012. Global land and water grabbing. Proceedings of the National Academy of Sciences 110(3):892-897. http://dx.doi.org/10.1073/pnas.1213163110

Sawyer, B. 2002. Serious games: improving public policy through game-based learning and simulation. Foresight and Governance Project, Woodrow Wilson International Center for Scholars Publication, Washington, D.C., USA.

Speelman, E. N., L. E. Garcia-Barrios, J. C. J. Groot, and P. Tittonell. 2014. Gaming for smallholders' participation in the design of more sustainable agricultural landscapes. Agricultural Systems 126:62-75. http://dx.doi.org/10.1016/j.agsy.2013.09.002

Stern, P. C. 2000. Psychology and the science of humanenvironment interactions. American Psychologist 55:523-530. http://dx.doi.org/10.1037/0003-066X.55.5.523

Thanichanon, P. 2015. Effects of market integration on land use and welfare in Xayaburi, Lao PDR. Dissertation. University of Bern, Bern, Switzerland.

Van den Top, G. M. 1995. The social dynamics of deforestation. Dissertation. University of Leiden, Leiden, The Netherlands.

Verburg, P. H. 2014. The representation of human-environment interactions in land change research and modelling. Pages 161-177 in M. J. Manfredo, J. J. Vaske, A. Rechkemmer, and E. A. Duke, editors. Understanding society and natural resources: forging new strands of integration across the social sciences. Springer Netherlands, Dordrecht, The Netherlands. http://dx. doi.org/10.1007/978-94-017-8959-2 8

van Vliet, J., H. L. F. De Groot, P. Rietveld, and P. H. Verburg. 2015. Manifestations and underlying drivers of agricultural land use change in Europe. Landscape and Urban Planning 133:24-36. http://dx.doi.org/10.1016/j.landurbplan.2014.09.001

Voinov, A., N. Kolagani, M. K. McCall, P. D. Glynn, M. E. Kragt, F. O. Ostermann, S. A. Pierce, and P. Ramu. 2016. Modelling with stakeholders - Next generation. Environmental Modelling and Software 77:196-220. http://dx.doi.org/10.1016/j.envsoft.2015.11.016

Vongvisouk, T., R. B. Broegaard, O. Mertz, and S. Thongmanivong. 2016. Rush for cash crops and forest protection: neither land sparing nor land sharing. Land Use Policy 55:182-192. http://dx.doi.org/10.1016/j.landusepol.2016.04.001

Walker, R., S. Perz, M. Caldas, and L. G. Teixeira Silva. 2002. Land use and land cover change in forest frontiers: the role of household life cycles. International Regional Science Review 25 (2):169-199. http://dx.doi.org/10.1177/016001760202500202

Wold, S., K. Esbensen, and P. Geladi. 1987. Principal component analysis. Chemometrics and Intelligent Laboratory Systems 2:37-52. https://doi.org/10.1016/0169-7439(87)80084-9 


\section{Appendix 1}

Ornetsmüller, C., J.-C. Castella, and P. H. Verburg. 2018. A multiscale gaming approach to understand farmer's decision making in the boom of maize cultivation in Laos. Ecology and Society

Full article available at https://www.ecologyandsociety.org 
Appendix 1 - Participatory mapping result as basis for village case selection

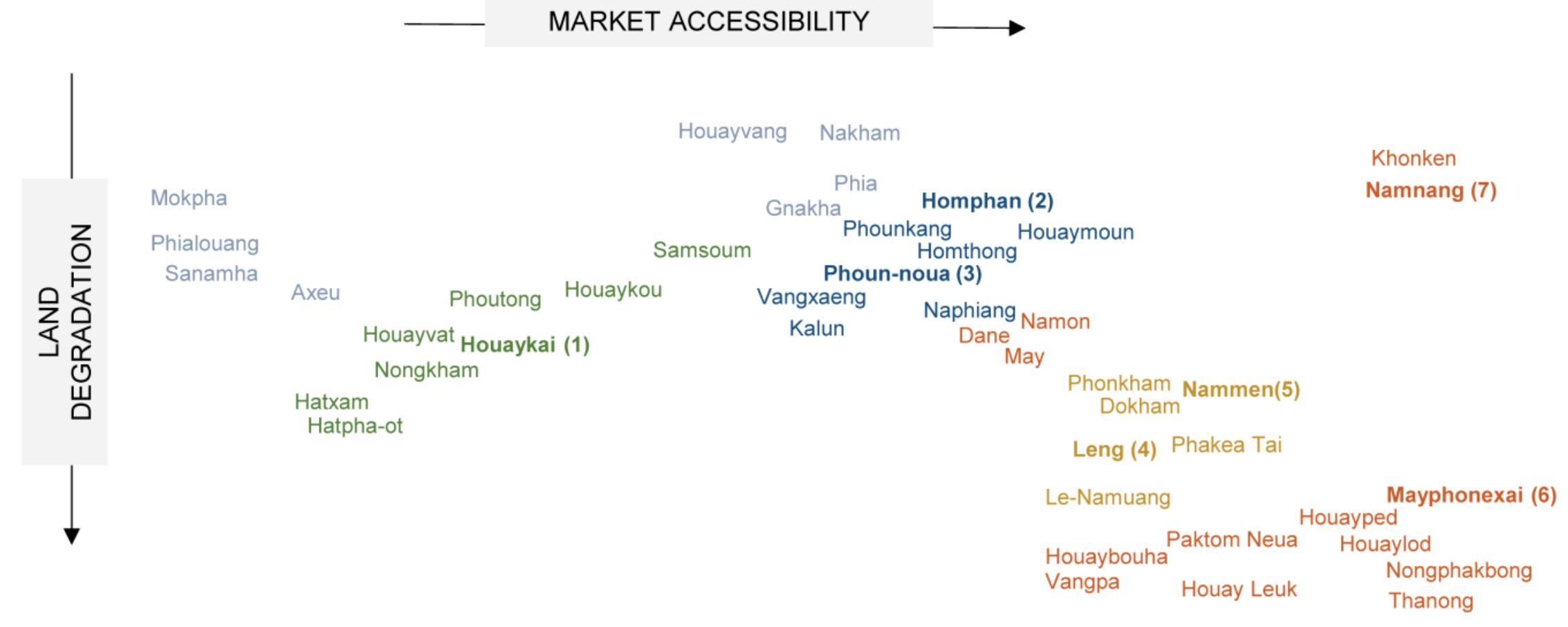

\section{Province}

Phongsaly - Louang Prabang - Houaphan - Xiengkhouang- Sayabouri

Figure A.1. EFICAS villages in respect to degree of market accessibility and land degradation mapped in a participatory workshop with experts. Bold villages were selected and surveyed chronologically according to the number in parentheses. Colors indicate respective province. Phongsaly Province was prone to an emerging maize boom as well, but had not yet engaged in hybrid maize cultivation at the time of our field work phase and was therefore not suitable to study the maize boom. 


\section{Appendix 2}

Ornetsmüller, C., J.-C. Castella, and P. H. Verburg. 2018. A multiscale gaming approach to understand farmer's decision making in the boom of maize cultivation in Laos. Ecology and Society

Full article available at https://www.ecologyandsociety.org 


\section{Appendix 2 - Local games}

Figure A.2.1. Description MAPRI Board Game developed in Houaykai

Basic game information

Name: MAPRI: Maize allocation and PRIce game

Research objective: to explore spatial maize allocation patterns and reactions to changes of selling prices of maize and rice in a spatially explicit board game

Player objective: allocate your land use relative to roads and river and manage your farm and household according to your wishes

Target audience: local smallholder farmers

Number of players: 12 participants play 6 households (2 participants per household): 3 farm household types are each represented twice (different household composition, wealth status, land uses)

\section{Resources}

(1) Board of $10 \times 10$ cells, 1 cell represents 1 ha plot, one road (red), two streams (blue)

(2) Household $(\mathrm{HH})$ cards specifying labour capacity and minimum consumption needs

(3) Numbers to identify land use cards of each $\mathrm{HH}$

(4) Land use (LU) cards: upland rice, young fallow, old fallow, maize. Fixed land uses: protected forest (hatched, no usufruct)

(5) Posters: (i) input/output for each land use, (ii) table to record results per $\mathrm{HH}$ per round

(6) Game money in MLAK (million Lao kip)

\section{Mechanics}

Rules. keep within $\mathrm{HH}$ labour capacity with land use choices, protected forest is not for agriculture. If minimum consumption needs not met, must give up farming.

Rounds $(n=3)$. Players first chose what and where to grow upland rice and maize in the next year. Second, all choices are recorded and money collected for activities with inputs. Third, revenues of farming minus family needs are paid to the players. Three rounds were played with different maize price announced before players chose land use: first medium, second high and third low maize prices while rice price remains constant.
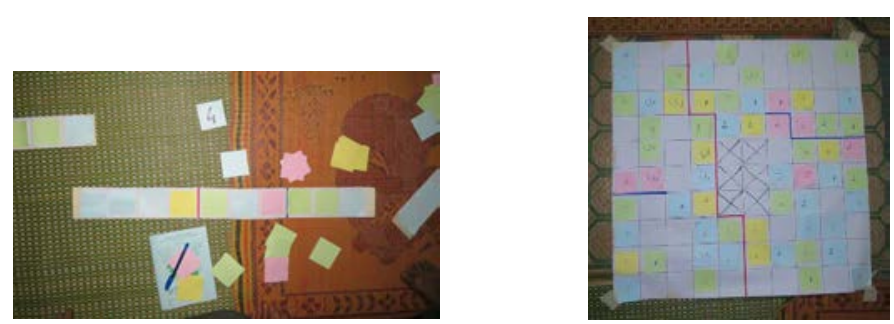

Paper strips used in explanation round and board after final round 
Figure A.2.2. Description MIALU Board Game developed in Homephan, Phoun-neua and Laeng

Basic game information

Name: MIALU - Maize Investments, Alternatives and related Land Use changes

Research objective: to explore what the profits from maize are invested in through a board game

Player's objective: manage your farm and household according to your wishes

Target audience: local smallholder farmers

Number of players: 12 participants play 6 households (2 participants per household): 3 farm types are each represented twice (different household composition, wealth status, land uses)

\section{Resources}

(1) Board of $10 \times 10$ squared cells, 1 cell represents a plot of 1 hectare

(2) Household $(\mathrm{HH})$ cards specifying labour capacity and minimum consumption needs.

(3) Numbers to identify land use cards of each $\mathrm{HH}$

(4) LU cards: upland rice, young fallow, old fallow, paddy rice, maize on good soil, maize on poor soil, opening fish ponds (added in game). Fixed land uses: village centre, protected forest, community forest

(5) Posters : (i) input/output for each land use and off-farm income: weaving, shop (added during game), (ii) table to record results per $\mathrm{HH}$ per round (iii) market offering livestock, houses, motorbikes, tractor, threshing machine, education, excavation service for paddy

(6) Game money in MLAK

\section{Mechanics}

Rules. keep within $\mathrm{HH}$ labour capacity. If minimum consumption needs not met, must give up farming. Protected forest is not for agriculture. Community forest and fallow may be used for bamboo harvest. Maize yield is lower if same plots used successive years.

Rounds ( $n=3$ ). First, players chose what and where to grow in the next year. Second, all choices are recorded and money collected for activities with inputs. Third, revenues of farming minus family needs are paid to the players. Fourth, players spend their money $(\mathrm{HH}$ consumption, agricultural investments, etc.) and make new land use choices for next year. In total, two full rounds with those four steps were played, with all rounds at fixed prices.

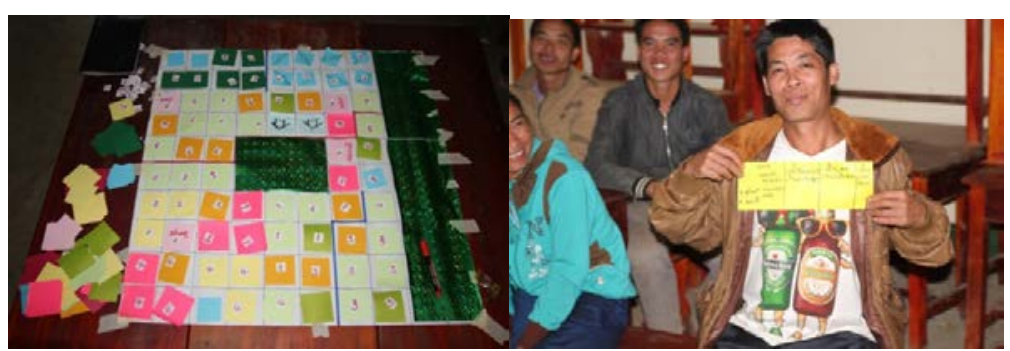

MIALU board and a player showing his household card 
Figure A.2.3. Description MaRISK Card Game developed in Namen

Basic game information

Name: MaRISK: Maize and RISK behaviour (card game)

Research objective: to explore land use related risk behaviour in a crisis

Player objective: manage your farm and household according to your wishes

Target audience: local smallholder farmers

Number of players: 12 participants play 6 households (2 participants per household): 3 farm household types are each represented twice (different household composition, wealth status, land uses)

\section{Resources}

(1) Household $(\mathrm{HH})$ cards specifying labour capacity, minimum consumption needs and the number of plots at the start

(2) LU cards: maize

(3) Posters: (i) parameters for maize inputs (labour needed per plot, costs for seeds, weeding, hired land and labour, buying land) and outputs (revenue per plot)

(4) Game money in MLAK

\section{Mechanics}

Rules: keep within $\mathrm{HH}$ labour capacity regarding number of maize plots. Loans can be taken at bank (played by facilitators). Options to buy (4 MLAK) or hire (1 MLAK) more plots (from either the facilitators or other $\mathrm{HHs}$ ) and to hire labour ( $3 \mathrm{MLAK})$. If a new plot is opened, expenses are added for first land clearance (0.5 MLAK).

Rounds $(n=3)$. The initial conditions allow each $\mathrm{HH}$ to survive in the first year (minimum costs of food and $\mathrm{HH}$ expenditures covered), but they can only afford the input costs for cultivating 1 out of their 3 plots with maize in the following year. First, players decide on how many plots they want to cultivate and in what way they finance their choices (own, hired plots, hired labour, loans for input). Second, they receive loan and/or pay for inputs or new plots. Third, the revenue is calculated and paid out to the players. In total, three full rounds were played with average yields in the first round, bad yields in the second and good yields in the third round.

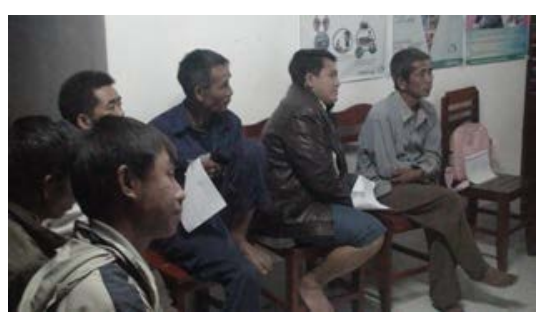

Participants during introduction to MARISK in the village Namen 
Figure A.2.4. Description of ranking workshop PALUM developed in Namen

Basic information

Name: PALUM - Preferred Alternative Land Uses to solve Maize problems (ranking)

Research objective: to explore preferences among proposed solutions to maize crisis

Player objective: rank different alternatives to current cropping techniques and land use

Target audience: local smallholder farmers

Number of players: 12 participants play 6 households ( 2 per household): 3 farm household types are each represented twice (different household composition, wealth status, land uses)

\section{Resources}

(1) Households are the same as in MaRISK, identification tokens with $\mathrm{HH}$ number

(2) LU cards (ranking options):

- $\quad$ maize intensification

o Pink: cultivation improvement (fertilizer, seeding machines)

- $\quad$ paddy

0
0

- livestock and feed

$$
\text { Yellow: Annual paddy rice }
$$

Dark green: Improved pasture for whole village

Light green: Improved pasture as a group (3-4 households)

Blue: Personal improved pasture

Dark red: Techniques on raising small livestock

(3) Tokens for voting (3 per player, not household)

\section{Mechanics}

Rules. Household ranking: pick four favoured options per household and place the first ranked on top, least ranked on bottom. Collective ranking: place three tokens to favoured options (among eight) - all participants at the same time.

Workshop structure. First, three facilitators played extension agents who presented in total eight options/alternatives to continue in/after maize crisis. Second, the individual $\mathrm{HH}$ ranked the alternatives from most to least preferred. Third, all players collectively voted for their preferred options with individual tokens (regardless of household they belonged to).

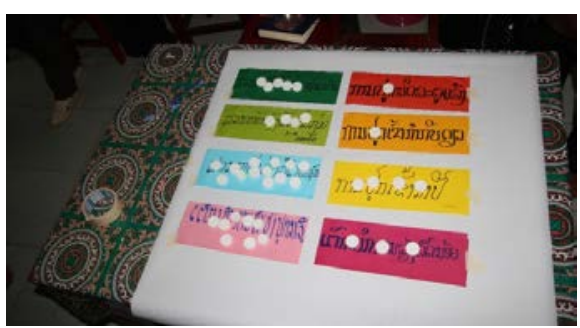

Result of collective voting for options/alternatives after maize crisis 
Figure A.2.5. Description MALAD Board Game developed in Mayphonexai

Basic game information

Name: MALAD - MAize and LAnd Degradation (non-spatial board game)

Research objective: to explore perception and response to maize-induced land degradation

Player objective: manage your farm and household according to your wishes

Target audience: local smallholder farmers

Number of players: 12 participants play 6 households (2 participants per household): 3 farm household types are each represented twice

\section{Resources}

(1) Board: the $8 \times 8$ cell board is only used to provide a frame rather than village representation, each $\mathrm{HH}$ plays on their own patch

(2) Household $(H H)$ cards specifying labour capacity and minimum consumption needs.

(3) LU cards: paddy, maize, red bean, cassava, pasture-livestock, tree plantation, off-farm activity

(4) Posters:

(i) parameters for each land use with input tokens (labour, financial, environmental) and output tokens (financial, environmental);

(ii) market goods and prices;

(iii) table to record results per $\mathrm{HH}$

(5) Tokens: blue $=$ labour force, white $=$ fictive money, red $=$ environmental value

\section{Mechanics}

Rules. Only land uses can be cultivated for which labour capacity and environmental quality sufficient, one $\mathrm{HH}$ after another announces decision and gets payment, facilitators make updates

Rounds $(n=4)$. Player pairs are formed and $\mathrm{HH}$ cards drawn, initial land use setting explained and cash given to each $\mathrm{HH}$ according to what their initial setting produces. First, players chose what to grow in the next year based on their labour force, environmental quality of their plots (red tokens) and necessary financial inputs (white tokens). Second, we calculate their revenue/pay out financial tokens and update the environmental quality for maize plots, cassava, red bean, pasture/livestock and tree plantation (paddy is neutral)
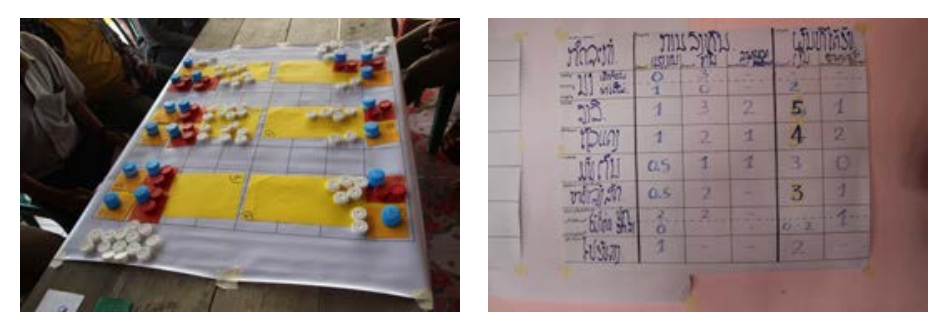

Initial setting on the board and poster with parameters 
Basic information

Name: TAKIT - (Take it!) Factors for adopting alternatives to maize

Research objective: to explore the prime factors for adoption of an alternative

Player's objective: decide whether to try out a new opportunity or not

Target audience: local smallholder farmers

Number of players: 12 participants play 6 households (2 participants per household): 3 farm household types are each represented twice (different household composition, wealth status, land uses)

\section{Resources}

(1) Household $(H H)$ cards specifying labour capacity and minimum consumption needs.

(2) Land use cards: maize, takit (fictive crop with attributes that are competitive to maize)

(3) Posters:

i) parameters for maize and takit

ii) collected questions organized in categories

(4) Maize grains for voting

(5) Energy drink and water for exemplary warm-up round

\section{Mechanics}

Workshop structure. Facilitators briefly offer two options (one old, one new) while describing only few details. HHs write down questions they have about options. Facilitators collect, categorize and write all questions on poster. HHs vote for most important question to them. Facilitators answer this question. HHs decide whether to take old or new option. Then they gather with those who decided like them for debriefing. Warm-up round with water (representing the known) and yellow fluid in a transparent bottle (i.e. an energy drink, representing the unknown). Actual maize alternative round with maize (representing the known) and takit (the new opportunity).

Rules. First note own questions, listen to answers by facilitators, then decide for own $\mathrm{HH}$

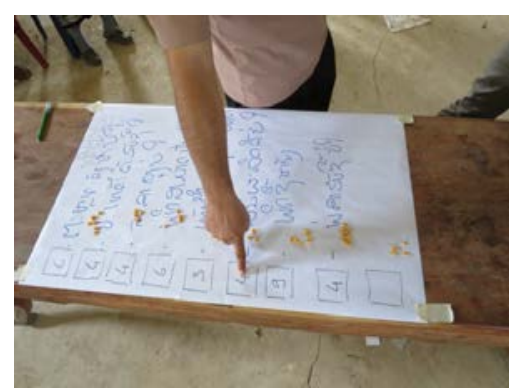

Voting results on most important question (factor) for adoption of an alternative crop 


\section{Appendix 3}

Ornetsmüller, C., J.-C. Castella, and P. H. Verburg. 2018. A multiscale gaming approach to understand farmer's decision making in the boom of maize cultivation in Laos. Ecology and Society

Full article available at https://www.ecologyandsociety.org 


\section{Appendix 3 - Mahasaly meta-game development process}

The Mahasaly game is based on the narrative of contexts, that influence decisions of farmers in the maize boom as described in Figure 4. Mahasaly incorporates elements of structure, parameters and lessons from the six local games presented in Appendix 2.

The MIALU and MALAD games in particular formed the basis for the board design, tokens and rules since they represented the re-investments in land and family and land degradation issues respectively and illustrate impacts of decisions on land use patterns. One round in the game equalled one cropping year, with subsections per round: i) land use choice and allocation, ii) announcement of harvest yields and payment of net revenues, iii) choice from consumption/investment market, announcement of new opportunities for the next year and taking credits if necessary. As in earlier games, the family orientation was represented via household cards indicating family members, labour capacity, minimum needs for family consumption and announcing the goal of the game to 'manage and develop your farm household'. Labour force was represented through round tokens that had to be put on the plot where they were 'working' in a respective round. Variations of market conditions (availability, stability, competitive alternative) stemmed from MAPRI (profitability and relativity of prices), MaRISK (opportunity and risk from credits) and TAKIT (competitive alternatives to maize). The market value of different land use options was represented on PowerPoint slides projected on the wall and through facilitators who acted and played the role of traders (two different maize traders, other trader offering opportunities with cassava and job's tears). To allow for an adoption phase we started with a situation where no maize is present - neither in the landscape, nor as an option on the market. The changes of market conditions were announced before each new round of land use allocation by displaying information on inputs and promised outputs per crop on PowerPoint slides. The consumption market goods were listed on posters indicating characteristics and prices. Participants could come to a small table (located beside the main playing table with the game board), where the consumption goods could be bought. Coloured papers around plots indicated land ownership of households, each being assigned a different colour. This allowed for quick visual analysis of changes as we monitored and debriefed land use patterns. Upland rice shifting cultivation was represented through a 3-steps cycle from upland rice, young fallow, old fallow with yield decreases if the same plot was cropped more than one year in a row. In reality cropping cycles include a 5 to 8 years fallow, but as we only played 6 rounds this simplified rule allowed to introduce key aspects of ecological degradation and regrowth dynamics in the limited time available. Furthermore, the livestock systems that were often mentioned in interviews and focus groups were incorporated in a simplified form to represent the attractiveness and risk of this farm activity while not getting lost in the complexity of crop-livestock interactions. Risk was introduced by announcing unpredictable disturbances to farmers such as livestock diseases or contract breaking by traders in the harvest phase of the round. These negative events affected the profit made from the respective 
land uses. They were deliberately planned by the researchers/facilitators of the game but unknown to the players at the time of choosing their land uses for the round.

Figure A.3. Description MAHA SALY game played with Lao agricultural experts in Vientiane Capital

Basic game information

Name: mahasaly - maize boom meta-game (spatially explicit board game)

Research objective: to evoke land use decisions that cause the maize boom and bust

Player's objective: manage your farm and household according to your wishes

Target audience: local agricultural experts

Number of players: 6 participants play 1 household each, 3 farm household types (different household composition, wealth status, initial land uses) each represented twice

\section{Resources}

(1) Board of $8 \times 8$ cells, 48 cells agriculture out of 64 cells total, small stream bordering 8 cells

(2) Household $(H H)$ cards: HH number, family size and minimum income

(3) Colored fences to identify land use cards of each $\mathrm{HH}$ on the board

(4) Land use cards: paddy, upland rice, young + old fallow, pasture, maize $\left(1^{\text {st }}\right.$ year on a plot good yield, $2^{\text {nd }}$ year less yield), cassava, job's tears, conservation forest

(5) Posters: (i) parameters for the land use choices available per round (inputs: financial and labour; outputs: yield, price and total revenue) (ii) market goods and prices; (iii) table to record results per $\mathrm{HH}$.

(6) Tokens representing labour force and game money in MLAK

\section{Mechanics}

Rules. paddy only along stream, no agricultural use of conservation forest, growing maize or upland rice repeatedly on same plot reduces yield, shifting cultivation requires 1 round-steps in sequence: upland rice, young fallow, old fallow;

Rounds $(n=5)$. First, players chose what and where to grow in the next year. Second, all choices are recorded and money collected for activities with inputs. Third, revenues of farming paid out, minus family needs. Fourth, players spend their money.

Changing conditions per round:

round 0: upland rice, paddy rice, livestock available as income generating land uses

round 1: trader 1 provides maize as opportunity (a. op.),

round 2: pest outbreak, all livestock infected and lost

round 3: pest outbreak reducing livestock by half, good revenue of maize

round 4: trader 1 breaks the contract and neither picks up nor pays for maize

round 5: trader 2 provides maize (a. op.) again, trader 3 provides job's tears and cassava

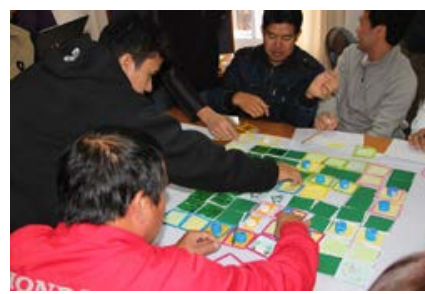

Experts allocating land use in mahasaly 